\title{
Geophysical Characteristic and Water Resources Availability in Rote Ndao, East Nusa Tenggara as a Basic for Coastal Tourism Development
}

\author{
Paul Gabriel Tamelan \\ Department of Vocational Technical Education, Faculty of Teaching and Education Studies, University of Nusa Cendana, \\ Kupang, East Nusa Tenggara, Indonesia
}

\begin{abstract}
East Nusa Tenggara has been known as an arid region in Indonesia. Water scarcity is among the crucial problems in East Nusa Tenggara. Recently, however, some area in East Nusa Tenggara has been developed as tourism area which is important for local economic development. Lands and water conservation therefore becomes the crucial issues in East Nusa Tenggara. The aims of the study are to indentify and describes the recent geophysical characteristics of land in Rote Ndao as a basic factor for water conservation and sustainable tourism development in arid environments. Field work and secondary data collection were done in Rote Ndao Regency, East Nusa Tenggara. Result of the study confirm that climates and rainfall was limited, but in some month there are heavy rain. Absent of land conservation strategy lead to the rapid runoff. The topography was undulating and if it is properly managed such structure can be used to support water conservation. Vegetation covers and quality was limited and it is becomes the barrier for water infiltration to soils. Therefore, the re-vegetation programs should be promoted widey in the island. It is especially important to enhance the susutainable coastal tourism destination in Rote Ndao.
\end{abstract}

Keywords: arid environment, soil conservation, tourism, water management

\section{INTRODUCTION}

Tourism in Rote Ndao Regency, East Nusa Tenggara, recently is growing significantly. The rapid international tourist arrivals in Rote Ndao led the area has declared as important tourism zone in East Nusa Tenggara Province. Throughout the world, tourism has been identified contributes to the local economic development. Tourism provides opportunities to open new economic activity and local business. In the same time, tourism contributes to the local culture promotion and empowerment. In East Nusa Tenggara, there are about 35 tourism object. Mostly it is consisted of natural objet and attractions. One of the most famous tourism destinations is Nemberala coast for surfing. There are also potential object and attractions such as wide sand sea, lakes, cave and historical monuments [1].

Tourism development in coastal ecosystem widely studied by numerous authors due to its potentiality to contributes negative impact to environment. Among the crucial phenomena in coastal tourism development is human migration to coastal area. These were followed by increasing tourism facility and land degradation which are decrease soil capability to absorb

\footnotetext{
${ }^{*}$ Correspondence address:

Name Paul G. TAmelan

Email : pagatama@ymail.com

Address : Fac. Teaching \& Education Studies, University of Nusa Cendana, Jl. Adisucipto, Penfui-Kupang
}

waters [2]. Study by Desrainy [3] found that uncontrolled urban development in JakartaBogor-Tangerang-Bekasi regions has changes rural and sub-urban area becomes densely populated regions. Such situation contributes to the rapid land uses changes, decrease of biodiversity, poor of food security, and urbanization [4]. The prospect of economic grows lead investor to establish numerous economic infrastructures in coastal regions.

Tourism development in Rote Ndao should consider environmental aspect, especially land management. It is particularly important because water as a crucial source was limited. Rote Ndao located in semi-arid environment in Indonesia with low rainfall intensity. The number of rainfall month was only 3-4 months yearly. The dry climates and lack of the management strategy of water resources lead water scarcity in Rote Ndao. Water is important not only for tourism development, but also for numerous human activities. Water is crucial resources to support human being. Therefore, it is government responsibility to draws the proper strategy for water conservations. Tourism development should be able to enhance and support water conservation. Therefore, tourism destination planning ad implementation should be put water as key issues in development. Beckerson and Walton in Harp [5] found that tourism development in England contributes to the water resources problems, especially to meet spa 
industry. Cristina argues that there are two important aspect related to water in rural environment. Firstly, in dry period, numerous of water spring and water resources were limited and people has difficulties to access water. Secondly, in rainy season when water abundance, there are difficulties to managed water to meet basic need of local community in villages.

In order to minimize negative impact of tourism on water resources, the comprehensive water resources management is important. It is especially important to provide sufficient water for community and tourism needs in water catchment area [2]. Wisnawa and Sutapa [6] point out that water resources conservation is important for environmental sustainability, and enhance the sustainability of water for the future. It is especially relevant in the case of tourism area such as Kuta and Sanur in Bali. The environmental conservation is especially important in order to mitigate negative impact which is related to the soil, land and water such as land slide.

In order to establish the proper management plant of natural resources, it is important to identify the basic characters of geophysical character of land in Rote Ndao Regency. Geophysical characters are one of the key indicators and important measurement aspect in development activity.

\section{Methods}

Field work and secondary data collection were done in Rote Ndao Regency, East Nusa Tenggara. Secondary data was collected from related office, i.e. Tourism office, Metereological office, Regional Planning Agency. Field survey was conducted at Rote Island. Focus of the observation is verification of the factual condition of Rote Ndao, especially for its lands physical characteristics, hidrologicla characteristics and vegetation characteristics. Data was analysed descriptively.

\section{General characters of Rote Ndao Regency}

Rote Ndao Regency with capital city called Baa, located at the southern part of Indonesian archipelago. Administratively, it was established by Undang-Undang No. 9 of 2002. The regency has an area about $1280,10 \mathrm{~km}^{2}$ which are consist of 107 islands. About eight island was inhabited by local people, namely Rote Island, Usu Island, Ndana Island, Nuse Island, Ndao Island, Landu Island and Do'o island. About 99 island was not inhabited. Rote Island is the the biggest island $(97.854 \mathrm{Ha})$ and become the tourism destination island in East Nusa Tenggara. All of the island has similar characteristics. The number of rainy season was about 3-4 month, and dry seasaon were about 8-9 month. Most of the rains with high storm.

Basically, the climates of Rote Ndao regency similar with other islands and area in east Nusa Tenggara. Rainy season was relatively short, from December to April yearly with air humidity about $85 \%$. Wind speed was recorded about 14 knot/hours, the average of air pressure about 966,7 millibars and the average of rainfall were about $800-1200 \mathrm{~mm}$ and air temperature ranging from $23.6^{\circ}-27{ }^{\circ} \mathrm{C}$. During few years ago, air temperature was increase significantly. The minimum temperature was recorded about $17.0^{\circ} \mathrm{C}$ and the maximum temperature was about $33.7^{\circ} \mathrm{C}$ with wind speed was about 0.9 knot/hours. Number of rainy days in 2013 was about 126 days. It is increased compared to the last years (about 104 days). The highest rainfall was recorded at January $(363,1 \mathrm{~mm})$, February $(359,8 \mathrm{~mm})$ and March $(328,8 \mathrm{~mm})$. Based on the rain fall map which was produced by Bakosurtanal and BMG 2004, the average of rainfall in West Rote sub-district was about 500 $1000 \mathrm{~mm}$. Based on the BMG data of Rote Ndao regency [1], it was recorded that during 10 years the monthly rainfall less than $100 \mathrm{~mm}$ was recorded at 8 month. Therefore, it was concludes that Rote Ndao Regency was dry.

The population of Rote Ndao regency in 2013 was recorded about 127.911 people. People density was about 100 people $/ \mathrm{Km}^{2}$ with population growth rate about $1.6 \% /$ year. The number of population with age more than 15 years about 65,928 individual [1].

\section{Lands physical characteristics}

The topography of Rote ndao area was undulating. About 32,625 Ha was hilly mountains and 45,250 Ha was flat area. The average of slope was about $45 \%$. The contour of Rote island was varies. The coastal area was about $0-10 \mathrm{~m}$ asl., while in the centre of island was about 200 $1500 \mathrm{~m}$ asl with land slope about $40-60 \%$. The land uses of Rote Ndao was dominated by forest, paddy field, plantation, settlement with home gardens and orchards.

Based on the Geology Map of East Nusa Tenggara in Figure 1 (sheet number 2205: Kupang Atambua) which area produced by Geology Research and Development Centre 
Bandung [7], most of the area has type Q1 Pleistosen or coraline limestone which were appears in soil periphery less than $60 \%$, while type Tmb is Bobonaro complex approximately about $30 \%$. The remaining area consist of type QTn or Noele formation with some little part of the coastal area was type Qa or Alluvium (Holocene). The age of the stones was classified into Quaternary.

\section{Hydrological characteristics}

According to hydro geological aspect, Rote Ndao has classified as tropical regions where watershed contain water in rainy season but water scare in dry season. Dry season has been identified long, about 7-9 month yearly. In Rote Nado Regency, Most of the area can be classified into $Q$ types (quatenary) and T type (tertiary), with rainfall average about $500-1000 \mathrm{~mm}$. About $10 \%$ of area have akuifer land with moderates productivity, water surface depth, and water flow $>5 \mathrm{lt} / \mathrm{s}$. Less than $60 \%$ of lands have akuifer produktif with limited ground water flow and there are many cracking, water flow potential $<5$ lt/s. About $30 \%$ is considered rare ground water zone with low productifity.

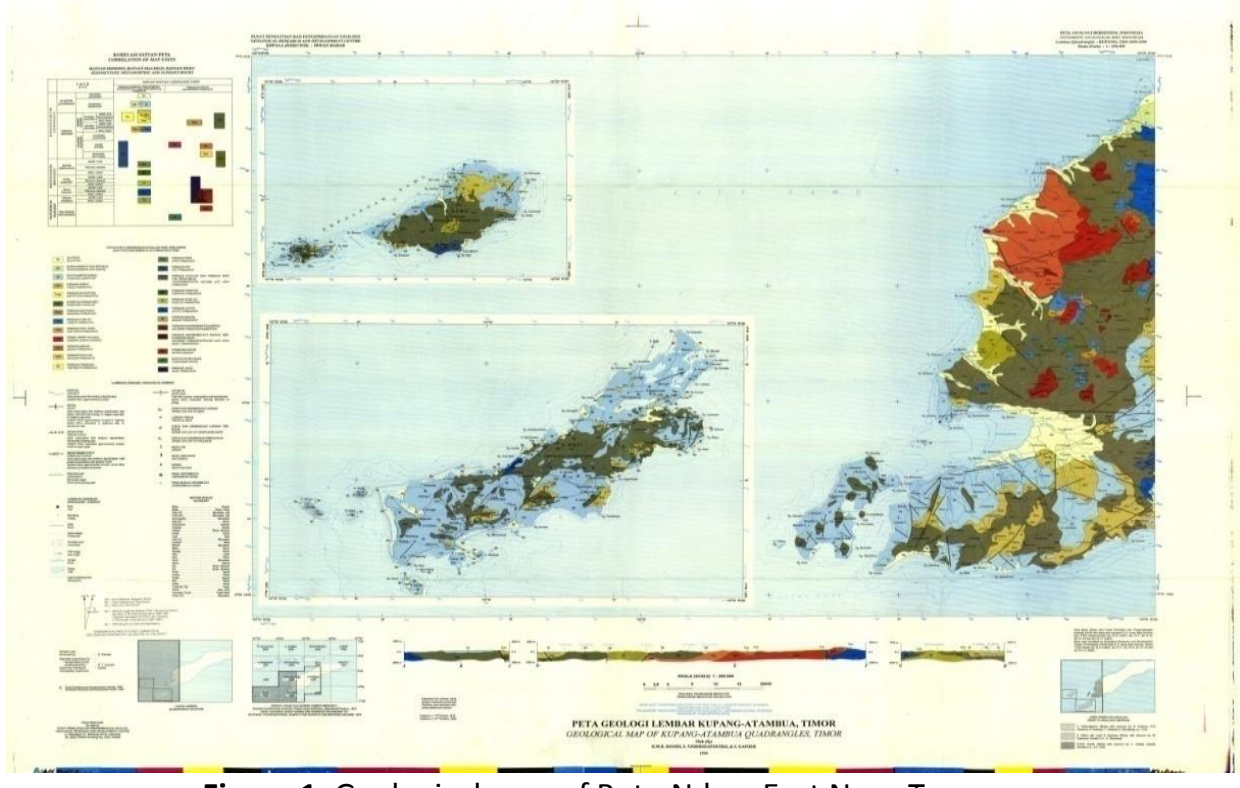

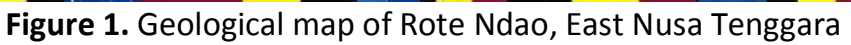

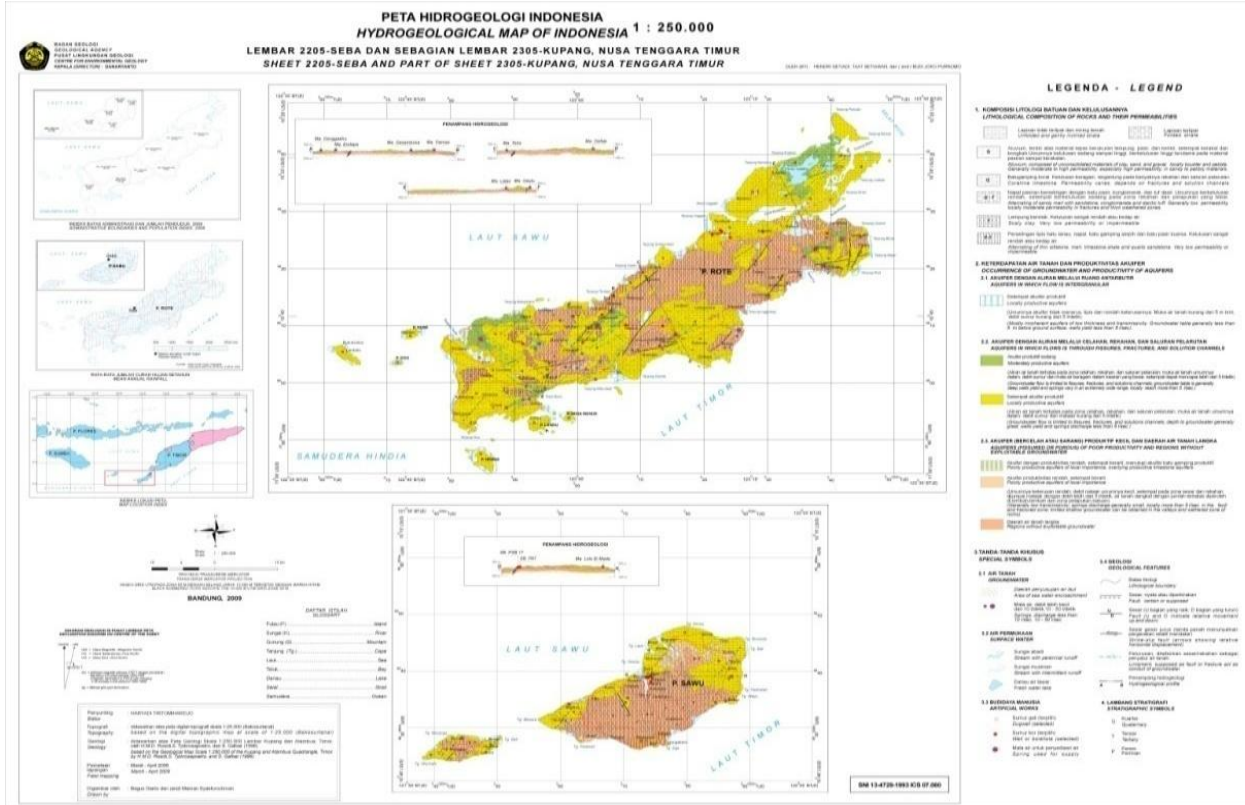

Figure 2. Hydrology map of Rote Ndao Regency NTT [8] 


\section{Vegetation characteristics}

Based on the statistics document and official document from Regional Planning Agency (Bappeda) Rote Ndao Regency in 2013, the land covers in West Rote sub district was drawn bellow (Table 1 ).

Table 1. Land uses allocation in Rote Ndao Regency, 2013

\begin{tabular}{llr}
\hline No & \multicolumn{1}{c}{ Types of land uses } & Size (Ha) \\
\hline 1 & Open space and settlements & 43,865 \\
2 & Dry orchards/home gardens & 3,945 \\
3 & Orchards (huma) & 4,247 \\
4 & Grazing area/ grasland & 24,546 \\
5 & Swamp area & - \\
6 & Aquaculture & - \\
7 & Water pool & - \\
8 & Barren lands & 1,309 \\
9 & Plantation & 5,021 \\
10 & State forest & - \\
11 & Community forest & 7,855 \\
12 & Dry lands & 10,591 \\
13 & Paddy field & 18,754 \\
14 & Others & 7,878 \\
\hline & Total & 128,010
\end{tabular}

Sources : BPS dan Bappeda Rote Ndao [1]

\section{DISCUSSIONS}

Local population and tourism in Rote Ndao

Based on the demographic data, the rate of population growth was recorded $1.6 \%$ yearly. The population density was estimated about 100 individual $/ \mathrm{km}^{2}$. About $75 \%$ of the community activity is farming in dry land. Some people works in forestry and fisheries sectors. Agricultural sector is one of the important sector in Rote Ndao, but as far its productivity was low. Dry environment, lack of water and poor technology and human resources seems to be the limited factor for agricultural productivity. Increasing agricultural productivity requires sufficient water for agricultural irrigation. Problems related water availability is water scarcity which are becomes the crucial limiting factor for productivity.

Regional planning to integrate numerous sector of development has been drawn. In such a case, however, the capacity of provincial and local government to establish the proper regional planning by involving water issues was important. It is especially important when tourism was consider as a new economic actitivity in Rote Ndao. Tourism can be separated from water resources. The challenges for water resources management in newly tourism destination is related to the water allocation for domestic needs, agriculture and tourism needs [8].

Tourism recently become intereting phenomena in Rore Ndao. Tourism grows significantly in West Rote, Lobalain and Central Rote sub district (Table 2). Both domestic and international tourism grows significantly. In the perpectives of water resources, however, such situation should be responded by water resources management. Growth of tourist followed by increse of tourism accomodation (i.e. hotel, lodge, home stay) and other tourist facility which can be separated by water resources [2].

Table 2. Tourist growth in Rote Ndao

\begin{tabular}{lrrrr}
\hline Subdistrict & \multicolumn{2}{c}{$\begin{array}{c}\text { International } \\
\text { tourist }\end{array}$} & Domestic tourist \\
& $\mathbf{2 0 1 0}$ & $\mathbf{2 0 1 2}$ & $\mathbf{2 0 1 0}$ & $\mathbf{2 0 1 2}$ \\
\hline West Rote & 736 & 1,050 & 97 & 331 \\
Lobalain & 13 & 4 & 949 & 1,596 \\
Central Rote & 15 & 25 & 300 & 257 \\
\hline
\end{tabular}

Land geophysical conditions

Based on the topography data, the landscapes of Rote Ndao Regency can be classified as steepest lands. Based on the Asdak classification [9], the land topography can be classified into several category, namely Class $1: 0$ - 8\% (flat), Class $2: 8-15 \%$ (flat), class $3: 15$ 25\% (moderate), class $4: 25-45 \%$ (steep) and class $5:>45 \%$ (steepest). There flat area found in coastal zone of the island where some part is undulating and form basins. These situation provides opportunities for water accumulation which are to penetrates to soils. These is similar with Arsyad [10] and Dewi et al. [11] arguments. The infiltration capacity and ground water storage was influenced by number of water which was flow in the surface of lands, especially in its amount and rain intensity. The highest degrees of slopes increases the water surface flows, and therefore increase the soil erosion hazards.

In case of Rote Ndao Regency with Q1 soil types-coral limestone-, the infiltration potential was low, but such stone formation provides opportunities for rain water infiltration due to the structure have numerous pores. In the case of Tnb types in Bobonaro complex, there area potentially for highest infiltration. In such structure, however, there are some land conservation techniques was needed to countermeasure landslides. A number of remains sand in such structure lead to the ability of water 
to transfer water into soil. Soils texture basically has relationship with soil pore. In case soil pores abundance, the infiltration capacity was high. Sartohadi [12] found that soil pores volume affect the rate of infiltration. Soil with number of soil pores has low weight. Conversely, soil with low pores has high weight, thus has high ability to absorb water [13]. In case of natural resources management, there are needs of research and studies related to the infrastructure and technology options to conserve water. Unsustainable uses of lands lead the increase and rapid land degradation [14]. In such a case there are positive relationships with water catchment area management as a crucial source to generate plant energy, irrigation, water spring management and other domestics needs.

\section{Hydrogeology}

The hidrogeological profiles of land in Rote Ndao provides opportunities for water infiltration to soils. It is especially related to the soil litology composition and karsts with higest levels of soils porosity. These process produces ground water which was found beneath the earth's surface [15]. Ground water quality was affected by climates, litology, times and human activity [16]. Similarly, Alwi and Marwah [17] point out that unsustainable uses of land and the absence of land conservation technology contributes to the negative impact water catchment area hydrology and water rivers quality of the area.

Having the important of infiltration process, there are important infiltration capacity research through hydrometereologic data and physical characteristics of water catchment area. It is similar with the case of sub-watershed Kreo which has highest rain fall in Garang water catchment area [18]. The water conservation therefore is important, especially in sustainable tourism lanning and development in Rote Ndao. In such a case, however, the detail and proper techniques was needed with special attention to the hydrogeological characteristics of location.

\section{Vegetations}

Based on the vegetation cover data of Rote Ndao Regency, it can be said that vegetation distribution and density was scare. It was calculated that community forest only $6 \%$ of the total area. About $34 \%$ of the total land was dominated by settlement and home garden, and about $19 \%$ was feeding ground. The dry and barren lands was calculated about $8 \%$. This figure shows that the number of vegetated area were low and needs to be improved in order to enhance water conservation.

Vegetation was the important factor for water conservation because its ability to absorb and stored water in hydro geological process $[19,20]$. The roots of vegetation also contributes significantly in soil protections and water infiltration. The roots of vegetation has important role in increasing soil permeability and therefore increase water infiltration.

Tourism facility and infrastructure development has been widely recognized contributes to the decreasing vegetation covers, especially in coastal area. Homegarden as a important spot in settlement area for water catchment area widely converted into numerous building and tourism facility to provides tourism basic needs. It is important for local government to drawn Regional Land Use Planning. Land uses changes has significant consequence for biodiversity and water conservation [2,21]. Forest and wildlife area conversation into settlement and tourism infrastructure affect negative impact of environment and biodiversity. Such changes contribute significantly to reduce natural water absorption zone and minimizersoil ability to absorb water.

According to governmental law number PP No. 43 Tahun 2008, water conservation should be implemented in integrated manners. These can be includes several key aspect namely, 1) soils protection and conservation; 2) ground water preservation; and 3) water quality management and protection of ground water from pollution. Moerwanto [22] argues that integrated water resources management is the process to enhance the integrity of development and water conservation, soil and other natural resources to increase the economical and society welfare by involving the issues of ecosystem sustainability. Tourism development cannot be separetd from environmental issues, including water resources management. Agriculture and soil management and technology should be promoted in order to meets the ecosystem sustainability issues, namely strip cropping and alley cropping. The physical techniques such as building terrace in steepest land was important. The proper management of land allow highest farmland productivity and therefore contribute to the local economic and farmer welfare. Moreover, the sustainable agriculture practices in dry land ecosystem has its potentiality to developed as one of the significant tourism attraction. 


\section{CONCLUSION}

Recent tourism development in Rote Ndao has close relationship with water issues. It is especially important because Rote Ndao physically located at dry environment where water scarcity become one of the crucial issues. Potential conflict between tourism and water can be minimized through proper water resources management. There are several important strategy to support water conservation in Rote Ndao. It is includes water infrastructure and catchment reservoirs (embung) constructions, bio-pore holes, re-vegetation of lands, especially in protected forest, production forest, home gardens and other potential locations as catchment reservoirs.

\section{REFERENCES}

[1] BPS and Bappeda Regency of Rote Ndao, 2014. Rote Ndao dalam angka. Rote Ndao.

[2] Hakim, L. 2002. Dasar-dasar Ekowisata. Bayu Media, Malang.

[3] Desrainy. 2010. Karakteristik wilayah Peri Urban pada Metropolitan Jabodetabekpunjur. Working Paper. Regional and Rural Planning Resarch Group. Bandung Institute of Technology.

[4] Mendoza, M. E., E. Granados, D. Genelétti. 2011. Analysing land cover and land use change processes at watershed level: a multitemporal study in the Lake Cuitzeo Watershed Mexico (1975 -2003). Applied Geography 31, 237-250.

[5] Harp, S. L. 2007. Histories of tourism: representation, identity and conflict. Journal of Social History 41 (1), 220- 221.

[6] Wisnawa, I M. B. and I K. Sutapa. 2014. Konflik air bersih sebagai akibat pengembangan sarana pariwisata pada Kawasan Bali Selatan dilihat dari perspektif perundang-undangan. Jurnal Perhotelan dan Pariwisata 4 (1), 95.

[7] Geology Research and Development Centre Bandung. 1996. Geology and Hydrogeology Map of Kupang Atambua 2205, East Nusa Tenggara.

[8] Mowforth, M and I. Munt. 2003. Tourism and sustainability: development and new tourism in the third world. Roudlege.

[9] Asdak, C. 2010. Hidrologi dan pengelolaan daerah aliran sungai. Gadjah Mada University Press. Yogyakarta.

[10] Arsyad, S. 2010. Konservasi tanah dan air. Bogor Agricultural University Press. Bogor.
[11] Dewi, I G. A. S. U., N. M. Trigunasih, and T. Kusmawati. 2012. Prediksi erosi dan perencanaan konservasi tanah dan air pada Daerah Aliran Sungai Saba. E-Jurnal Agroekoteknologi Tropika 1 (1).

[12] Sartohadi, J. 2012. Pengantar geografi tanah. Pustaka Pelajar. Yogyakarta.

[13] Effendi, A. D. 2008. Identifikasi kejadian longsor dan penentuan faktor - faktor utama penyebabnya di Kecamatan Babakan Madang Kabupaten Bogor. Faculty of Forestry, Bogor Agricultural University. Bogor.

[14] Sylviani. 2010. Potensi dan pemanfaatan sumberdaya air di Daerah Aliran Sungai Jeneberang dan Kawasan Hutan Lindung (Studi kasus di Kabupaten Gowa, Propinsi Sulawesi Selatan). Jurnal Penelitian. Makassar.

[15] Hasmar. H. 2010. Drainase terapan. Islamic University ofIndonesia Press. Yogyakarta.

[16] Hariyono. 2011. Uji bakteriologis air di Kecamatan Semampir Surabaya. Airlangga Universitas.

[17] Alwi, L. O. and M. Sitti. 2014. Dampak penggunaan lahan terhadap sumber daya air: Studi Literatur Dan Hasil Penelitian, Universitas Halu Oleo, Kendari. Jurnal Agroteknos 4 (2), 134-145.

[18] Suhandini. 2011. Banjir bandang di DAS Garang Jawa Tengah (penyebab dan implikasinya). PhD Thesis. Faculty of Geography, Gadjah Mada University. Yogyakarta.

[19] Chen, H., J. Liu, W. Zhang W., and K. Wang. 2011. Soil hydraulic properties on the steep karst hillslopes in northwest Guangxi China. Journal of Environment Earth Science, 1-9.

[20] Eze, E.B., D.I. Eni, and O. Comfort. 2010. Evaluation of the infiltration capacity of soils in Akpabuyo local geverment area of Cross River, Nigeria. Journal of Geography and Geology 3 (1), 189-190.

[21] Azmeri, H. B. and N. Herissandy. 2012. Analisis pengaruh perubahan lahan terhadap ketersediaan air DAS Krueng Meureudu. Faculty of Engineering, Syiah Kuala University. Jurnal Ekonomi dan Pembangunan 3 (1).

[22] Moerwanto, A. S. 2013. Penyusunan pola pengelolaan sumber daya air selesai pada tahun 2015. Direktorate of Water Resources Management. Jakarta. 